\author{
BULETINUL INSTITUTULUI POLITEHNIC DIN IAŞI \\ Publicat de \\ Universitatea Tehnică „Gheorghe Asachi” din Iaşi \\ Volumul 67(71), Numărul 1, 2021 \\ Secţia \\ CONSTRUCTTII. ARHITECTURĂ \\ DOI: $10.2478 /$ bipca-2021-0004 \\ sciendo
}

\title{
USE OF LIMESTONE BLOCKS IN CONSTRUCTIONS IN THE REPUBLIC OF MOLDOVA
}

BY

\begin{abstract}
ALBU DOINA-CEZARA*
„Gheorghe Asachi” Technical University of Iaşi, Faculty of Civil Engineering and Building Services, Iasi, Romania
\end{abstract}

Received: May 12, 2020

Accepted for publication: February 06, 2021

Abstract. One of the most important problems in modern society is the problem of using natural, ecological, harmless products for humans. In construction, this problem is solved by selecting, combining and using natural, traditional materials for some geographical areas. The most widespread in the world, starting from antiquity, is limestone. The limestone block, the so-called „cotileț”, is a construction material that has been used in masonry for over 60 years on the territory of the Republic of Moldova. In this research is considered dynamic extraction of limestone blocks, are analysed existing excavations and its location, the limestone reserves in Moldova. The technical characteristics of the „cotilet," are studied, such as dimensions, density, water absorption level, softening coefficient and earthquake resistance. At the same time, the existing buildings on the territory of the Republic of Moldova were examined and the characteristics of those built of limestone blocks were highlighted.

Keywords: excavations, construction material, masonry, applicability, technical characteristics.

\footnotetext{
${ }^{*}$ Corresponding author; e-mail: doina-cezara.albu@student.tuiasi.ro (C) 2021 Albu Doina-Cezara

This is an open access article licensed under the Creative Commons Attribution-NonCommercialNoDerivatives 4.0 International License (CC BY-NC-ND 4.0).
} 


\section{Introduction}

The limestone blocks or the so-called Moldavian cotilet represent pieces cut in the shape of a parallelepiped from limestone. Cotilet is a traditional construction material on the territory of Moldova. The widespread use of this stone in the construction of buildings has given a special flavour to Moldovan cities.

The first extractions of the cotilet date back to the 15th century near the town of Cricova, not far from Chisinau. The Republic of Moldova ranks second in the CIS after Russia in terms of reserves explored by the cotilet (Sidorov, 2006). The name of the material cotilet is a Russian transliteration of the word shell. That type of limestone contains inclusions of sea mollusc shells and fragments thereof, which are visible to the naked eye when examining the structure of the rock.

The cotilet occupies a special place in Moldovan culture. The Director General of the State Agency for Geology of the Republic of Moldova, Gena Prano Jalalite, noted that the well-known cotilet stone is a high-quality building material, representing the geological wealth of Moldova among non-metallic minerals (Sidorov, 2006).

In this paper the author examines the dynamics of limestone block extraction, existing excavations and reserves of limestone on the territory of the Republic of Moldova, the technical characteristics of the cotilet and its use in construction.

\section{Limestone blocks in Republic of Moldova}

\subsection{Extraction of limestone blocks on the territory of Moldova}

During the Soviet period, the Azurit company produced more than 650,000 cubic meters of building materials, including the cotilet. In total, Moldova produced up to 1.25 million cubic meters of material annually (Sidorov, 2006). By 2000, production had fallen to 298,000 cubic meters, but by 2005 there was a trend of growth - more than 400,000 cubic meters were produced. After four years the trend has changed its vector towards a decrease in the extraction of limestone blocks from the territory of the Republic of Moldova which is shown in Fig.1. 


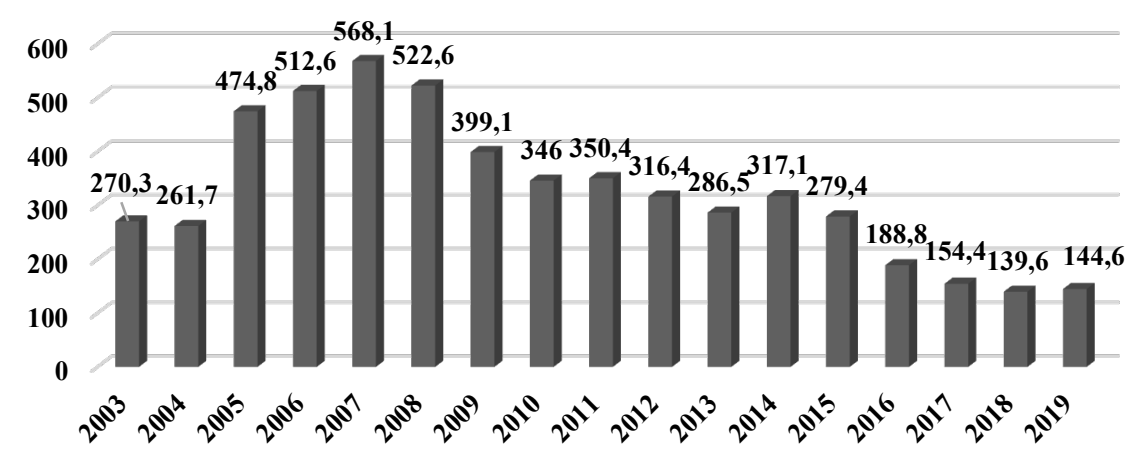

Fig. 1 - Extraction of limestone blocks, thousand $\mathrm{m}^{3}$ (National Bureau of Statistics, 2019)

According to official data (Resurse minerale ale Republicii Moldova, 2021), there are 166 excavations of limestone in the Republic of Moldova (Fig. 2) of which 59 are used for cutting the blocks (Fig.3).
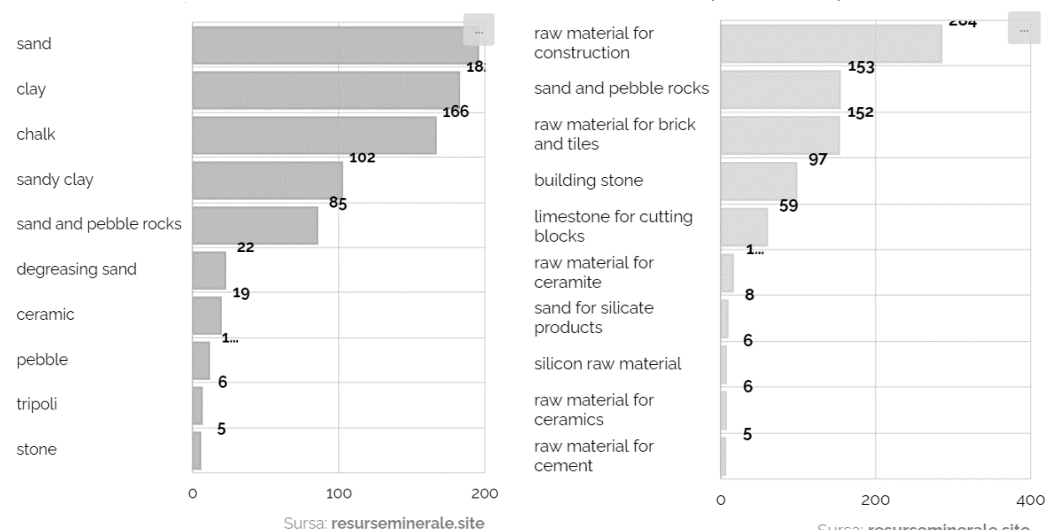

Fig. 2 - Number of excavations in Moldova: $a$ - by mineral substances; $b$ - by raw material

Table 1

Limestone quarries in Moldova

\begin{tabular}{||c|c|c|c||}
\hline District & Town & Recovery & $\begin{array}{c}\text { Reserve, } \\
\left(1000 \mathrm{~m}^{3}\right)\end{array}$ \\
\hline \hline municipality Chisinau & zone Riscani & exploit & 91.283 \\
\hline municipality Chisinau & city Cricova & exploit & 146.692 \\
\hline municipality Chisinau & village Fauresti & exploit & 70.035 \\
\hline municipality Chisinau & village Goian & exploit & 12.526 \\
\hline
\end{tabular}




\begin{tabular}{|c|c|c|c|}
\hline District & Town & Recovery & $\begin{array}{l}\text { Reserve, } \\
\left(1000 \mathrm{~m}^{3}\right)\end{array}$ \\
\hline municipality Chisinau & village New Goian & exploit & 25.146 \\
\hline municipality Chisinau & village Braila & exploit & 800 \\
\hline Orhei & $\begin{array}{l}\text { village Branesti, } \\
\text { village Jeloboc, } \\
\text { village Morovaia }\end{array}$ & exploit & 77.232 \\
\hline Edinet & $\begin{array}{c}\text { village Volodeni } \\
\text { village Gordinesti } \\
\text { village Tirnova } \\
\text { village Old Chetrosica }\end{array}$ & exploit & 13.097 \\
\hline Dubasari & $\begin{array}{l}\text { village Holercani } \\
\text { village Cocieri }\end{array}$ & exploit & 7.212 \\
\hline Riscani & village Druta & exploit & 12.936 \\
\hline Criuleni & $\begin{array}{l}\text { village Grand Hirtop } \\
\text { village Mascauti } \\
\text { village Pascani }\end{array}$ & exploit & 89.262 \\
\hline Rezina & $\begin{array}{l}\text { village Lalova } \\
\text { village Lipceni } \\
\text { village Mereuti }\end{array}$ & exploit & 37.755 \\
\hline Ialoveni & village Milestii Mici & exploit & 26.056 \\
\hline Ocnita & city Ocnita & exploit & 102.992 \\
\hline Soldanesti & village Mihuleni & $\begin{array}{l}\text { ready to } \\
\text { use }\end{array}$ & 13.836 \\
\hline New Aneni & village Calfa & $\begin{array}{c}\text { ready to } \\
\text { use }\end{array}$ & 12.396 \\
\hline Ocnita & village Birnova & $\begin{array}{l}\text { reserve } \\
\text { holding }\end{array}$ & 17.968 \\
\hline municipality Tiraspol & $\begin{array}{c}\text { village Bicioc } \\
\text { village Valea Adinca } \\
\text { village Ofatinti } \\
\text { village Crasnaia Gorca } \\
\text { city Grigoriopol } \\
\text { village Mihailovca } \\
\end{array}$ & $\begin{array}{l}\text { reserve } \\
\text { holding }\end{array}$ & 258.574 \\
\hline Riscani & village Vartic & $\begin{array}{l}\text { reserve } \\
\text { holding }\end{array}$ & 1.527 \\
\hline Soroca & village Visoca & $\begin{array}{l}\text { reserve } \\
\text { holding }\end{array}$ & 1.204 \\
\hline Edineti & village Gordinesti & $\begin{array}{l}\text { reserve } \\
\text { holding }\end{array}$ & 2.140 \\
\hline
\end{tabular}

The limestone stock used in construction constitutes 1.129.291 thousand $\mathrm{m}^{3}$ (Table 1), divided into 2 holdings prepared for exploitation, 13 reserve holdings and 44 quarries in operation. 
Most limestone quarries in the Republic of Moldova are located in the central area (Resurse minerale ale Republicii Moldova, 2021). The map location of limestone quarries is shown in Fig.3.

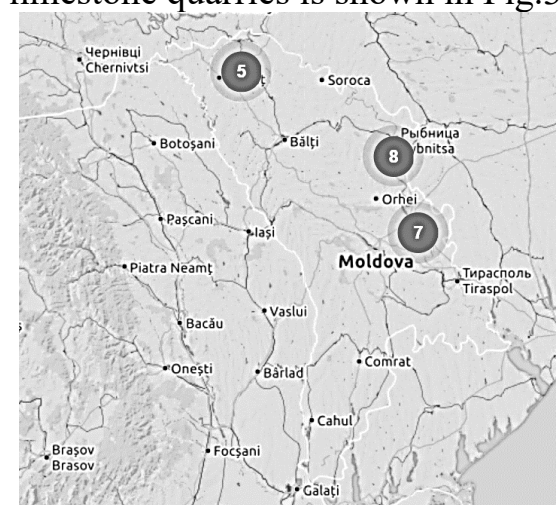

Limestone quarries in reserve

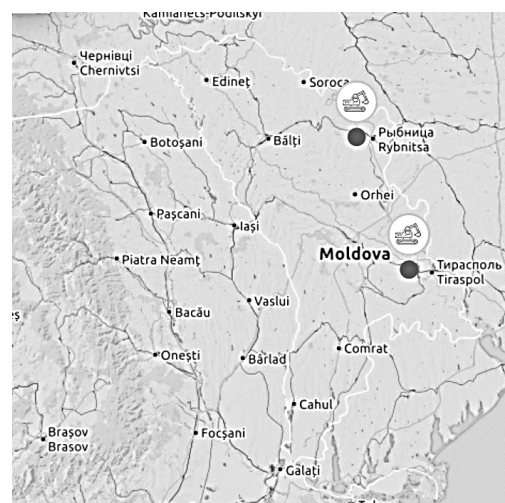

Limestone quarries prepared for operation

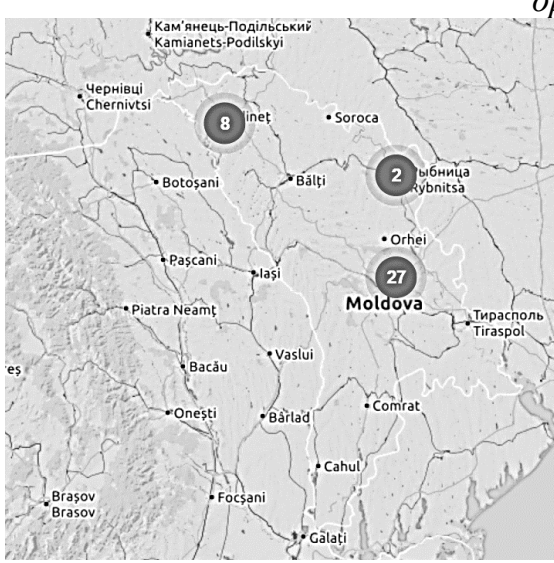

Exploited limestone quarries

Fig. 3 - Location of limestone quarries in the Republic of Moldova

Not every limestone stone can become building material. But the one used in construction is different. For example, the one extracted in the mine from Chisinau differs from the one extracted in the mines from Cricova or Milestii Mici. The one extracted in the capital can "boast" with excellent characteristics for building the exterior walls or their cladding. The layers of the cotilet from Chişinău were made up of marine sediments from the historical period of the Middle Sarmat, the so-called oolitic limestone. The oolites gives a superior strength to the Chisinau stone (Fig. 4), unlike the corresponding products from other tens of Moldovan mines, where also limestone stone is extracted but already with shells (Oguzov, 2012). 
The oolitic limestone consists of spherical or ellipsoidal calcite oolite aggregates varying in size from fractions of millimetres to 2-2.5 $\mathrm{mm}$, cemented by cryptocrystalline carbonate (oolitic structure). The oolites have a concentriczonal structure, less common radial-radial, and in the center of each of them is the smallest shell fragment, a grain of sand or a grain of calcite (Uchebnyy kabinet geologii, 2019).
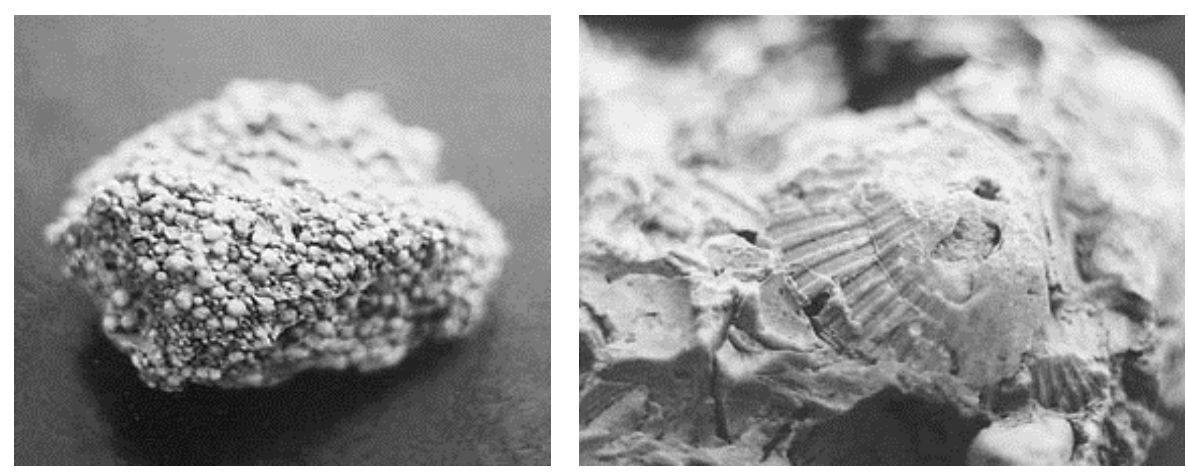

Fig.4. - Limestone: $a$ - with oolites (Uchebnyy kabinet geologii, 2019); $b$ with shells (Prokopovich, 2006)

The limestone with shells (Fig. 4) is part of the group of organogenic limestone, it is light, porous, white, yellow or grey, almost entirely composed of large shells $(0.5-2 \mathrm{~cm})$ of molluscs or fragments of these shells (Uchebnyy kabinet geologii, 2019).

A limestone quarry that is at the heart of the development of the limestone block extractor industry in the Republic of Moldova is the "Mineral" mine founded in September 1946 and is located in Cricova. At the beginning, the miners' jobs were lit with gas-fired lamps and the miners cut 15-20 small blocks of natural limestone by hand with a saw. At the end of 1953, the extraction of stone was introduced with the help of stone cutters invented by C. Galaninii, which liquidated manual labour. Due to this technology from 1946 to 1975 the productivity of stone extraction was increased 17 times. If in 1953 the extracted volume was $5,000 \mathrm{~m}^{3}$ of construction stone, then in 1974-159,000 $\mathrm{m}^{3}$ (S.A. Mineral, n.d.).

In the mines of Cricova, 3 in number, limestone blocks of 3 marks are extracted: 25, 35 and 50. And in the "Baumall Mineral" mine in Fauresti, located just $12 \mathrm{~km}$ from Chisinau, limestone blocks of the brand 75 are extracted.

\subsection{Technical characteristics of limestone blocks}

Blocks of limestone extracted in the Republic of Moldova are subject to verification based on Russian quality standards GOST 4001-84 "Stone for masonry made of natural rocks. Technical conditions' (GOST 4001-84, 2001). 
Blocks of limestone are of 2 types: basic - for building walls with subsequent plastering of walls; facade - to build walls that do not require subsequent plastering.

The small blocks of cut limestone used for wall brickwork are made of sizes 390x190x188 and 490x240x188 mm, with marks 25, 35 and 50.

Large blocks of limestone cut by marks 35 and 50, with cross-sectional dimensions $390(490)$ x $380 \mathrm{~mm}$, are produced in lengths up to $1380 \mathrm{~mm}$ (NCM F.03.02-2005, 2005).

According to the quality standards, the small and large blocks of cut limestone used for the exterior walls of the plastered masonry buildings with normal hydrothermal regime must withstand without signs of deterioration at minimum 6 cycles of frost at a temperature of $-15^{\circ}$ and thaw at a temperature of $+15 \pm 5^{\circ} \mathrm{C}$. The cotilet in the mines of Moldova has a minimum threshold of 10 clicks.

Blocks of limestone of mark 25 are used for walls of buildings with height up to 3 levels, with seismicity of calculation 6 degrees and ground floor buildings with seismicity of calculation 7 degrees. And blocks of limestone of 35 mark are used for walls of buildings with height up to 9 levels, with seismicity calculation $6 \ldots 9$ degrees. In the case of blocks of limestone 50 mark are used for walls of buildings with height up to 12 levels, with calculation seismicity 6 degrees and height up to $7-10$ and 5 levels with calculation seismicity $7-8$ and 9 degrees respectively (NCM F.03.02-2005, 2005).

The Moldavian cotilet has a density of $1700-1900 \mathrm{~kg} / \mathrm{m}^{3}$, seismic resistance being 8 degrees on the Richter scale. This building material is environmentally friendly and absorbs water at 14-18\% with a softening coefficient of 0.7-0.9, which requires masonry plastering.

\section{Use of limestones blocks in Moldova}

The construction industry in the Republic of Moldova uses limestone blocks - Large-scale cotilet since the 50s of the last century. The first buildings in limestone blocks were the cult buildings, built of carved blocks. The buildings of kindergartens, schools and high schools in Chisinau are built of limestone blocks.

The type of buildings "Stalinka" have a planning of 3 types of apartments with areas of 30-35 $\mathrm{m}^{2}$ - a room, with two rooms - 50-55 $\mathrm{m}^{2}$, with three rooms $60-70 \mathrm{~m}^{2}$.

While the type of buildings "Khrushchevka" have a planning of 4 types of apartments with surfaces of $30,6 \mathrm{~m}^{2}, 39,3 \mathrm{~m}^{2}, 44,1 \mathrm{~m}^{2}$ and $59,3 \mathrm{~m}^{2}$.

Also, the type of buildings "Brezhnevka" have a planning of 4 types of apartments with areas of $30.4 \mathrm{~m}^{2}, 43.1 \mathrm{~m}^{2}, 53.3 \mathrm{~m}^{2}$ and $70 \mathrm{~m}^{2}$.

The type of buildings "Czech" has a planning of 3 types of apartments with areas of $30.6 \mathrm{~m}^{2}, 53 \mathrm{~m}^{2}$ and $70 \mathrm{~m}^{2}$. 
Table 2

Types of buildings built from cotilet in Chisinau

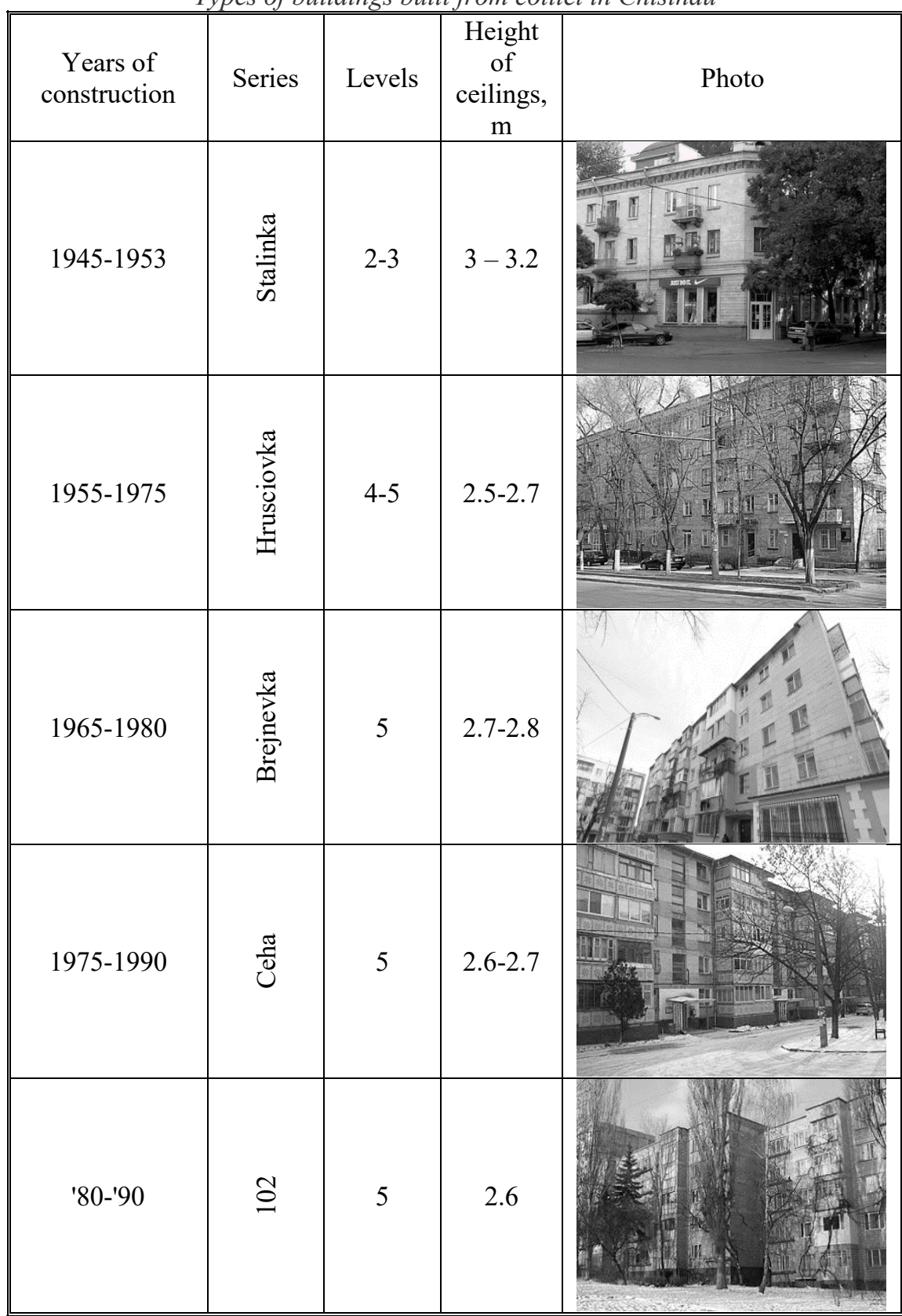

The 102 series of buildings have a planning of 5 types of apartments with the following areas of $31.6 \mathrm{~m}^{2}, 32.5 \mathrm{~m}^{2}, 50 \mathrm{~m}^{2}, 54 \mathrm{~m}^{2}, 73 \mathrm{~m}^{2}, 74 \mathrm{~m}^{2}$ and $84.5 \mathrm{~m}^{2}$. 
Limestone block - the cotilet nowadays is widely used for the construction of individual houses, also for the erection of multi-storey residential blocks being building material for exterior and interior filling walls.

\section{Conclusions}

In the conclusions I would like to point out the advantages of the cotilet:

One of the main advantages is being part of ecological materials, material that "breathes".

Another advantage of the cotilet is its life span of over a century, which is confirmed by the state of the buildings presented in Table 2, which already have an actual life span of approx. 60 years.

Earthquakes in Moldova are quite common. And a small seismic effect can affect the structural integrity of a building. But the ones built from the sheathing stand up to 8-9 on the Richter scale.

The shell also carries increased fire resistance, is the material that allows to ensure the security and preservation of the integrity of the structures in case of fire.

The structure of the cotilet allows to minimize the vibration of the sound waves, which characterizes it as a material with high sound insulation qualities, creating a high comfort in the rooms.

The massive use of limestone blocks in buildings in the Republic of Moldova is attested for over 60 years. The built blocks of this material have a relatively high lifespan.

Acknowledgements. The research was carried out within the project 20.80009.0807.34 Increasing the value of architectural heritage of the Republic of Moldova.

\section{REFERENCES}

GOST 4001-84, 2001. Natural rock wall blocks. Specifications, Russia: M .: Gosstroy of Russia.

National Bureau of Statistics, 2019. Production of main industrial products. [Online] Available at:

https://statbank.statistica.md/PxWeb/pxweb/en/40\%20Statistica\%20economica /40\%20Statistica\%20economica_14\%20IND_IND030/IND030100.px/?rxid $=9 \mathrm{a} 62 \mathrm{a} 0 \mathrm{~d} 7-86 \mathrm{c} 4-45 \mathrm{da}-\mathrm{b} 7 \mathrm{e} 4-\mathrm{fecc} 26003802$

NCM F.03.02-2005, 2005. Proiectarea clădirilor cu pereți din zidărie, Chisinau: Agenția pentru dezvoltarea regională a Republicii Moldova.

Oguzov, D., 2012. V chetyrekhkilometrovoy shakhte pod Kishinevom do sikh por dobyvayut material dlya stroitel'stva. [Online] Available at: https://point.md/ru/novosti/obschestvo/v-chetirehkilometrovojshahte-pod-kishinevom-do-sih-por-dobivayut-material-dlya-stroiteljstva 
Prokopovich, L., 2006. MNOGOLIKIY IZVESTNYAK. [Online]

Available at: https://www.nkj.ru/archive/articles/3277/

Resurse minerale ale Republicii Moldova, 2021. Analitica. [Online]

Available at: https://www.resurseminerale.site/ro/graphic

S.A. Mineral, n.d. Despre companie. [Online]

Available at: http://mineral.fabricatinmoldova.com/rom/company/

Sidorov, D., 2006. Po dannym razvedki: geologicheskoy. [Online]

Available at: http://www.nm.md/article/po-dannym-razvedki-geologicheskoy/

Uchebnyy kabinet geologii, 2019. Izvestnyak. [Online]

Available at: http://geology.brsu.by/content/izvestnyak

\section{UTILIZAREA BLOCURILOR DE CALCAR ÎN CONSTRUCTIILE DIN REPUBLICA MOLDOVA}

\section{(Rezumat)}

Una dintre cele mai importante probleme din societatea modernă este problema utilizării produselor naturale, ecologice și inofensive pentru oameni. În construcții, această problemă este rezolvată prin selectarea, combinarea și utilizarea materialelor naturale tradiționale pentru anumite zone geografice. Cel mai răspândit în lume, începând cu antichitatea, este calcarul. Blocul de calcar, așa-numitul „cotileț”, este un material de construcție folosit de zidărie de peste 60 de ani pe teritoriul Republicii Moldova. În această cercetare se consideră extracția dinamică a blocurilor de calcar, sunt analizate săpăturile existente și amplasarea acesteia, rezervele de calcar din Moldova. Sunt studiate caracteristicile tehnice ale „,cotilețului”, cum ar fi dimensiunile, densitatea, nivelul de absorbție a apei, coeficientul de înmuiere și rezistența la cutremur. În acelaşi timp, au fost examinate clădirile existente pe teritoriul Republicii Moldova şi au fost evidențiate caracteristicile celor construite din blocuri de calcar. 